Engle, Paul, ed. Midland: Twenty-five Years of Fiction and Poetry, selected from the Writing Workshops of the State University of Iowa. New York: Random House, 1961.

Florida, Richard. The Rise of the Creative Class. New York: Basic Books, 2002. Glass, Loren. "Middle Man: Paul Engle and the Iowa Writers' Workshop." the minnesota review 71-72 (2009): 256-68.

Guillory, John. Cultural Capital: The Problem of Literary Canon Formation. Chicago: University of Chicago Press, 1993.

McGurl, Mark. The Program Era: Postwar Fiction and the Rise of Creative Writing. Cambridge, MA: Harvard UP, 2009.

Myers, D. G. The Elephants Teach: Creative Writing Since 1880. Chicago: University of Chicago Press, 1996.

Wilbers, Stephen. The Iowa Writers 'Workshop. Iowa: University of Iowa Press, 1980.

Loren Glass is Associate Professor of English at the University of Iowa. His first book, Authors Inc.: Literary Celebrity in the Modern United States, 1880-1980, was published by New York University Press in 2004. He is co-editor, with Charles Williams, of Obscenity and the Limits of Liberalism, forthcoming with Ohio State University Press. He is currently writing a study of Grove Press.

\title{
Bartholomew Brinkman: Imitations, Manipulations and Interpretations: Creative Writing in the Critical Classroom
}

'What's so great about 'In a Station of the Metro?' It's a couple of lines and it doesn't even rhyme. I could write that." A familiar question, no doubt, to anyone who has attempted to teach the poem. In response, I've trodden the regular routes: Textual Analysis ("Let's look at the images and the role of punctuation."), Biography ("It took Pound two years to whittle it down from thirty lines."), History ("Consider how the poem engages with modernity through mass transportation and the crowd."). But I've also added another response to this repertoire: "If you think you could write that, well then, why don't you?"

Over the past few years, I've been assigning creative imitations and manipulations in my undergraduate literature classrooms and have seen a marked improvement in students' understanding of - and interest in - literary genre and form. Not only an interest in how complex themes and subjects can be effectively conveyed in a villanelle, a scenic description, or an exchange of dialogue, but a profound interest in technique for its own sake, as we consider what distinguishes the poem, the novel, the short story, the essay. In bringing creative writing into the critical classroom, I have also attempted to frame literary study as not only reception, but also as production - and as an ongoing interchange between reception and production - that provides an example of what Gerald Graff has advocated as "teaching the conflicts"3 (Graff). Students can better understand and articulate their thoughts on a topic as they adopt, adapt, react to, and frame their critical responses in the language of specific literary texts. To be most effective, however, creative pedagogy needs to extend beyond individual texts and classrooms to more fundamentally structure the literary discipline as a whole. 
I have certainly not been alone in my attempts to bring the creative and the critical more closely together. Teachers have often introduced creative elements into the critical classroom; a few have written up their experiences and have attempted some pedagogical generalizations based on their success. These reports from the front share the basic assumptions that an inquiry-based pedagogy allows students to draw on their own wide-ranging experiences and to assert personal authority in terms of subject matter as they come to grips with the particular literary text (van Oostrum 556; Everett 233). These pedagogical practices are guided by an understanding that students often learn texts from the inside out as they wrestle with the processes of literary making and unmaking.

Such pedagogy needs to be more widespread, reaching out to a generation of students who often can't tell their iambs from their assonance. But students can hardly be blamed for what is largely an institutional shortcoming. While I am deeply sympathetic to the academy's historical, cultural, and material turns over the past few decades and draw on these insights in my teaching and research, I recognize too that they have come with a cost. Instructors often feel fundamentally ill-equipped to teach literature in its specificity; they choose, rather, to treat formal elements as uncomplicated vehicles for displaying historical events and ideological commitments without being able to identify — let alone making a case for the significance of - such basic textual building blocks as character, plot, and poetic meter.

While there has been a resurging critical interest in aesthetics and form as it relates to literary history and larger cultural forces, marked by such recent movements as New Formalism, it is unclear to what extent this interest will be imported into the undergraduate classroom. Those who advocate neo-formal approaches are already comfortable with the specificity of form and are undoubtedly engaging with formal issues in their classrooms. While many in the academy may - and hopefully will - reap the benefits of their conclusions, it admittedly requires more catch-up to employ their methods in research and teaching. In the immediate future, then, it is likely that, apart from a decided minority of literary critics who feel comfortable enough to do the job themselves, we will often leave basic literary elements to be taught (if at all) in the increasingly ubiquitous creative writing classroom.

But this presents its own problems. As Shirley Geok-lin Lim has argued, there is an institutional "strangeness" to creative writing. This strangeness has created a gulf between creative and critical pedagogy that — as a product of both creative and critical programs - I have experienced firsthand from opposite and often distant banks. As Lim argues, while it is a significant part of the employed profession, creative writing often seems to be on the margins of the discipline, the mainstay workshop or tutorial structure lacking what could be called a coherent methodology or object of study and the practice of creative writing rejecting the relationship between teaching and scholarship that underpins the discipline as a whole. While some creative writing instructors have seriously reflected on the critical possibilities and responsibilities of the creative classroom - especially as it applies to composition instruction, recognizing its usefulness in teaching the fundamentals of all good writing - and while this reflection has increased in recent years (spurred on by, among other things, the popularity of the creative writing Ph.D. that requires a 
demonstration of both creative and critical acumen), it is clear that the discipline as a whole requires greater introspection. ${ }^{4}$

Lim concludes her provocative essay not with an indictment of creative writing, but with a challenge to the discipline as a whole. If creative writing is to be recognized as a complementary discipline, she writes, "its inherent resistance to and necessary integration into the intellectual and academic work of English must likewise be performed" (165). This is, however, easier said than done. There are not only significant ideological differences between critical and creative instructors, but also conflicts over a finite set of resources - including money, office space and faculty appointments - that often make integration next to impossible. Historically, literary studies and creative writing have been at best strange bedfellows, at worst sworn enemies.

There are, however, definite steps that can be taken to improve the situation. One of those steps I am advocating is for literary instructors to employ creative imitations and manipulations - common procedures in creative writing pedagogy and once the preferred method of instruction in literary studies as well, but for several decades now a rare occurrence in the critical classroom. I have successfully used imitation as a teaching tool in various literary genres, asking students to write stories in James Joyce's stream-of-consciousness or dramatic scenes with Tennessee Williams's elaborate stage directions. Even as students desire to abstract from the text-summing it up as being about love or death or, perhaps in a bit more nuanced reading, as forwarding issues of class division or religious reconciliation-imitation foregrounds form and specific language that must be taken into account as directives and correctives to grander meaning. Students must consider what marks a given author's style. They must slow down and think about the specifics of the text before they begin to abstract from it. In short, they must closely read the poem, story, or play if they hope to make something like it. And in making something like it they reinforce their reading.

I have employed several kinds of imitations and manipulations in my classes. On the most basic level, I have asked students to simply mimic a literary element or device; often, I have extended this practice to the imitation of a full poem or fictional scene or to variations on a particular textual form such as the sonnet. In addition to encouraging imitations, I have challenged students to manipulate texts as well, as when I ask them to rewrite a poem or a scene from one author in the style of another: Wallace Stevens' "The Snow Man" in the dialect-heavy style of Langston Hughes; a sparse scene by Ernest Hemingway in the paid-by-the-word loquaciousness of Charles Dickens. This is only a small sampling of possible imitation and manipulation exercises - that I encourage instructors to use, augment and transform to best serve their particular students and course objectives - but it begins to point to what is possible with creative pedagogy. Imitations and manipulations help students to transition from passively accepting the importance of poetic elements to actively discovering their necessity.

Many of these assignments can be done during a class period, as a private writing exercise, or in pairs; others would be more suitable as take-home assignments. In either case, I have found it helpful to ask students to defend their creative decisions. In the classroom, this may be accomplished in small-group or full-class workshops. 
When assigning take-home exercises, I require a page or so of critical prose explaining what the student has done (or what the student thinks he or she has done, which is quite often not the same thing). While the imitated text itself displays much of the student's understanding of the original, the prose explanation helps to clarify and articulate - for both student and instructor - that understanding (for this reason, I believe that critical explanations should be used more frequently in creative writing courses as well). Students need to not only explain in what specific ways their texts are imitations, but what is significant about the elements they have imitated, and indeed why they chose to imitate their particular texts in the first place. Such an explanation requires that they employ the terminology we have been discussing in class and helps keep students accountable for the creative choices they've made. Students generally welcome the chance for critical clarification, since many of them are anxious about whether their ideas are getting across and would like an opportunity to explain their intentions. It also allows them to further practice the critical essay form as they compare and contrast the source text and their imitation, generally keeping them away from such pitfalls as the ubiquitous "five-paragraph" format and the temptations of plagiarism.

The prose facilitates grading as well. Admittedly, grading the imitated or manipulated text can be difficult. While I still contend with those B/B- borders and feel a tinge of disappointment at giving a deservedly bad grade, just as I do with more traditional essays, I am especially careful not to crush a student's creative spirit. A well-praised successful imitation can fuel a new interest in writing; a poor and harshly judged one can quell it. Some students may be more practiced at creative writing or have more innate talent, and these students should be encouraged - but not at the expense of other students in the class. I make it clear in my grading rubric, then, that I am not grading the creative writing per se; it can be about any inoffensive subject, a straight imitation or a parody. My focus is on how well the student identifies, imitates or manipulates and explains the importance of particular elements. The critical prose is particularly helpful here: if a student recognizes that a poem is in iambic pentameter, attempts iambic pentameter in their imitation and isn't fully successful but clearly explains what they were trying to do (even admitting where they had trouble), I am likely to give a lot of credit for the attempt.

Through formal and informal feedback, I have confirmed that students learn from and genuinely enjoy these creative exercises and assignments. In the past, recognizing that students signed up for a critical class and not a creative one, I have given students the choice of a more traditional close reading assignment of longer length. I have found, however, that many of my students are budding writers (or would simply like a change from the standard literature assignment) and overwhelmingly chose the creative option anyway. The creative assignments give them an opportunity to do what they enjoy while at the same time encouraging them to think about their own practices in a critical way. Having witnessed the success of the imitated poem time and again, however, and recognizing that it is an option that will likely not be available in other literature courses, I have since made creative assignments a requirement.

Aside from giving students a more grounded understanding of the particular 
text, creative imitations and manipulations help students take charge of their own learning. Rather than passively listening to their instructors dictating the importance of textual elements - often with little obvious context or application - the student actively investigates those elements that seem most important to the text at hand. Students collaborate with instructors to realize their personal creative goals, which frequently feed into larger critical ones.

As such, imitation and manipulation provide a useful entrée into other literary issues. Although imitation and manipulation would seem to engage less directly with theoretical and historical questions that drive many literature courses, the foregrounding of prosodic and stylistic elements - of close reading and close writing - help to make these questions particular to the text at hand. For this reason, I generally assign creative exercises early in the semester, using them as the proving ground for elements and terminology we have recently discussed and a solid basis from which we can consider larger contextualizing questions without losing sight of the specificity of the text. I have used the imitation assignment in a number of different courses - introductory genre courses in fiction and poetry, introduction to literary studies, survey of American literature, poetry after 1940-with a great deal of success. While each of these courses develops different skill sets and encourages different kinds of questions, I feel that in all of the courses subsequent papers and in-class discussions have been enriched by the close attention to detail learned through imitation and manipulation.

I am not arguing, however, that the critical literature course should be conflated with the creative writing one. Each serves a different purpose: the former is ultimately focused on literary reception (though this is often articulated through critical production), the latter on literary production (though this often involves critical reception). While I have been arguing for the adoption of creative writing pedagogy in the critical classroom (and, less explicitly, for more critical pedagogy in the creative writing classroom), I see little danger of one course being subsumed into the other. Nonetheless, I am advocating a more direct interchange between creative and critical pedagogy, along with a more explicit articulation of assumptions and aims, than has often been the case.

While I have been primarily concerned here with explaining how an individual instructor can bring creative imitation and manipulation into the literary classroom, I want to conclude by suggesting that the interchange does not need to stop at the level of individual pedagogical practice. It should also involve more sustained efforts at pedagogical collaboration between literature and creative writing instructors and should inform approaches to teaching by the profession as a whole. Greater collaboration during individual class sessions or for full courses would allow instructors to learn from one another, both in subject and style, and to bring that knowledge back to their individual courses (perhaps even to their writing and research). There can also be greater institutional collaboration, at both the departmental and professional levels, where literature and creative writing faculty participate together in workshops and conferences focused specifically on teaching. While in other dimensions of their professional lives creative writing and literature faculty often seem to pass like ships, ghosts or clichés in the night—generally not 
publishing in the same journals, not attending the same conferences or even the same talks on campus - the classroom is potentially one site of productive overlap.

Creative pedagogy gives students more coherent exposure to multiple views and contrasting approaches to reading literature than they may otherwise receive in the critical classroom. This lets them better understand and productively interact with particular texts in a variety of contexts and theoretical frameworks, rather than being forced to haphazardly piece together a critical strategy as they bounce from pedagogy to pedagogy as surely as they move from class to class. In the short run, creative pedagogy will help students better address the particular elements of the literary text in conjunction with larger social, historical and theoretical issues; in the long run, it will help to foster greater communication between, and respect for, both critical and creative perspectives as it promotes a more thorough integration of the literary discipline as a whole.

\section{Notes}

1 Graff, with the help of co-authors, has since more specifically articulated his notion of teaching the conflicts to academic writing, arguing for the importance of argumentative templates - which frequently involve creative acts of imitation and manipulation. See Gerald Graff, Cathy Birkenstein, and Russel Durst, eds., They Say/I Say: The Moves That Matter in Academic Writing, With Readings (New York: W. W. Norton, 2009).

${ }^{2}$ As Anna Leahy has argued, for example, creative writing classrooms are particularly well suited to take on such critical issues as the role of grammar. See Anna Leahy, "Grammar Matters: A Creative Writer's Argument," Pedagogy 5.2 (2005): 304-308.

\section{Works Cited}

Everett, Nick. "Creative Writing and English." The Cambridge Quarterly 34.3 (2005): 231-42.

Graff, Gerald. Beyond the Culture Wars: How Teaching the Conflicts Can Revitalize American Education. New York: W. W. Norton, 1992.

Lim, Shirley Geok-lin. "The Strangeness of Creative Writing: An Institutional Query." Pedagogy 3.2 (2003): 151-69.

Van Oostrum, Duco, Richard Steadman-Jones and Zoe Carson. "Taking the Imaginative Leap: Creative Writing and Inquiry-Based Learning." Pedagogy 7.3 (2007): 556-66.

Bartholomew Brinkman is a Doctoral Candidate in English at the University of Illinois at UrbanaChampaign. He is currently completing his dissertation on modern transatlantic poetry and print culture, "By the Book: Book Collecting, Scrapbooking and the Making of Modernism, 1880-1950." His essay grows out of a paper originally delivered at the 2009 MLA convention. 